Article

\title{
Optimal Allocation of Surface Water Resources at the Provincial Level in the Uzbekistan Region of the Amudarya River Basin
}

\author{
Min Wang $1,2,3,4,5$, Xi Chen ${ }^{1,2,4,5,6, *}$, Ayetiguli Sidike ${ }^{7}$, Liangzhong Cao ${ }^{8}\left(\mathbb{D}\right.$, Philippe DeMaeyer ${ }^{1,2,3,4,5}(\mathbb{D})$ \\ and Alishir Kurban 1,4,5 \\ 1 State Key Laboratory of Desert and Oasis Ecology, Xinjiang Institute of Ecology and Geography, \\ Chinese Academy of Sciences, Urumqi 830011, China; wangmin17@mails.ucas.edu.cn (M.W.); \\ Philippe.DeMaeyer@UGent.be (P.D.); alishir@ms.xjb.ac.cn (A.K.) \\ 2 University of Chinese Academy of Sciences, Beijing 100049, China \\ 3 Department of Geography, Ghent University, 9000 Ghent, Belgium \\ 4 Sino-Belgian Joint Laboratory of Geo-Information, 9000 Ghent, Belgium \\ 5 Sino-Belgian Joint Laboratory of Geo-Information, Urumqi 830011, China \\ 6 Research Center for Ecology and Environment of Central Asia, Chinese Academy of Sciences, \\ Urumqi 830011, China \\ 7 School of Management, Xinjiang Agricultural University, Urumqi 830052, China; ruth136@163.com \\ 8 College of Tourism and Geogrphy, Jiujiang University, Jiujiang 332000, China; liangzhong.cao@outlook.com \\ * Correspondence: chenxi@ms.xjb.ac.cn
}

Citation: Wang, M.; Chen, X.; Sidike, A.; Cao, L.; DeMaeyer, P.; Kurban, A. Optimal Allocation of Surface Water Resources at the Provincial Level in the Uzbekistan Region of the Amudarya River Basin. Water 2021, 13, 1446. https://doi.org/10.3390/ w13111446

Academic Editor: Hao Wang

Received: 29 March 2021

Accepted: 17 May 2021

Published: 21 May 2021

Publisher's Note: MDPI stays neutral with regard to jurisdictional claims in published maps and institutional affiliations.

Copyright: (c) 2021 by the authors. Licensee MDPI, Basel, Switzerland. This article is an open access article distributed under the terms and conditions of the Creative Commons Attribution (CC BY) license (https:/ / creativecommons.org/licenses/by/ $4.0 /)$.

\begin{abstract}
Water users in the Amudarya River Basin in Uzbekistan are suffering severe water use competition and uneven water allocation, which seriously threatens ecosystems, as shown, for example, in the well-known Aral Sea catastrophe. This study explores the optimized water allocation schemes in the study area at the provincial level under different incoming flow levels, based on the current water distribution quotas among riparian nations, which are usually ignored in related research. The optimization model of the inexact two-stage stochastic programming method is used, which is characterized by probability distributions and interval values. Results show that (1) water allocation is redistributed among five different sectors. Livestock, industrial, and municipality have the highest water allocation priority, and water competition mainly exists in the other two sectors of irrigation and ecology; (2) water allocation is redistributed among six different provinces, and allocated water only in Bukhara and Khorezm can satisfy the upper bound of water demand; (3) the ecological sector can receive a guaranteed water allocation of $8.237-12.354 \mathrm{~km}^{3}$; (4) under high incoming flow level, compared with the actual water distribution, the total allocated water of four sectors (except for ecology) is reduced by $3.706 \mathrm{~km}^{3}$ and total economic benefits are increased by USD 3.885B.
\end{abstract}

Keywords: Uzbekistan; Amudarya River; water allocation; optimization; ITSP method; Aral Sea

\section{Introduction}

Uzbekistan is one of the countries suffering the most pressing water challenges [1,2], with the average water consumption per capita since 2000 amounting to just $88.29 \mathrm{~m}^{3}$, which is much less than the world average. The Amudarya River, of which the total flow amounts to $78.46 \mathrm{~km}^{3}$ /year [3], is one of Uzbekistan's two main water sources, and it covers most parts of the country. However, in its middle and lower reaches, water losses when the river flows through the desert and water withdrawals by agriculture account for a substantial portion of the total flow, and as a result, the flow reaching the Aral Sea is less and less. The water volume of the Aral Sea has already decreased by three-fourths of what it had been in 1960, and this is famously known as the Aral Sea crisis [4-6], which is mainly blamed on the mismanagement of water resources [7,8]. The Aral Sea is the largest inland tail-end lake in arid Central Asia and plays a very important role in the local water resources and ecological environment [9]. Aral Sea's drying has already led to 
a series of negative consequences in local areas and even the entire Central Asia region, such as spreading and intensifying desertification, local climate change, and increasing threats to the residents' health $[10,11]$. As one of the two main supply rivers of the Aral Sea, the Amudarya River is almost used up by riparian countries. While the water resources are limited, the water demand has been increasing as the population and economy grow, which has intensified water use competition among different water users. Even more, water shortage throughout Uzbekistan is especially severe in dry water years [12-14], which could hamper economic development and ecological protection and even threaten national security.

Given the water challenges in Uzbekistan related to balancing economic development and ecological sustainability, and the unreasonable use of water resources from the Amudarya River, there is an obvious need to explore the optimization of the portion of water resources from the Amudarya River distributed to Uzbekistan. Although a number of researchers have focused on water allocation in the Amudarya River Basin [15-22], there has been a limited amount of research on water allocation schemes among different water use sectors (irrigation, livestock, industry, municipality, and ecology) at the provincial level within the current practical water management framework. Lutz et al. (2012) built the water system at the basin level, starting from Kulyab (Tajikistan) and ending at the Aral Sea, and they also obtained the water-allocation schemes among different hydro-units; however, they did not include the administrative units, and some practical water diversion agreements were neglected. The situation is similar to the case of Schluter et al. (2005 and 2006), who built a water management model for Amudarya River at the whole basin level, and especially focused on the delta region. Afterward, Jalilov et al. $(2011,2016)$ built a hydro-economic model in the Amudarya River Basin, which brings the basin's hydrology and economics into a single framework for policy analysis, but its emphasis is on how upstream reservoirs' operation influences the potential economic benefits of riparian countries. Most of these previous studies built related models of the whole river basin or ignored the importance of current water policies and thus failed to take into account the existing water distribution quotas among four Central Asian republics, which were approved by the USSR in 1987 and are still being executed; therefore, these models cannot be directly used to understand the current challenge in Uzbekistan. Furthermore, all of the above research does not consider the uncertainties, which are important and inevitable in the process of water distribution.

The purpose of this paper is to address the current water challenge situation in Uzbekistan in the Amudarya River Basin. The main contents of this paper are (1) to build the whole water system of the target area at the provincial level based on current international water diversion policies; (2) to calculate the water supply and water demand in the study area and to make the supply-demand balance analysis; (3) to calculate the coefficients of economic benefit and economic penalty as input data for the optimization model; (4) to apply the inexact two-stage stochastic programming (ITSP) optimization model for water allocation work by considering uncertainties, and to discuss the results and draw conclusions; (5) to conduct the comparison between the optimized and the actual water-allocation schemes. This paper will help guide local water managers to make decisions on water allocation among different water users of different provinces.

\section{Study Area}

The study area is located at $38^{\circ} \mathrm{N}-46^{\circ} \mathrm{N} / 56^{\circ} \mathrm{E}-68^{\circ} \mathrm{E}$ in Central Asia arid zones, as shown in Figure 1. It has special climate characteristics because it is mainly influenced by the westerly jet stream and the North Atlantic Oscillation. It is hot and dry in summer, cold and wet in winter. The annual precipitation rarely exceeds $200 \mathrm{~mm}$, and annual evaporation is nearly $2000 \mathrm{~mm}$. The coldest month is January, and the temperature in the north drops to $8{ }^{\circ} \mathrm{C}$ and below, and in the south, it is above $0{ }^{\circ} \mathrm{C}$. The hottest months are July and August, and the average temperature on the plains and foothills is $25-30^{\circ} \mathrm{C}$, while in the south it reaches $41-42{ }^{\circ} \mathrm{C}$. The Amudarya River is a transboundary river, originating 
from the Pamirs Mountains and formed by the union of Panj River (Tajikistan) and Vakhsh River (Afghanistan). It then flows northwest into Turkmenistan, then to Uzbekistan, and finally into the Aral Sea through a broad delta. In the middle and lower reaches of the Amudarya River, oases are distributed along the river banks, with the Karakum Desert and Kizilkum Desert on both sides. The Kashkadarya River flows in the Sogd province in Tajikistan and Kashkadarya province in Uzbekistan. The Zarafshan River rises at the Zeravshan Glacier in Tajikistan and evaporates in the Kyzylkum Desert near the city of Bukhara in Uzbekistan.

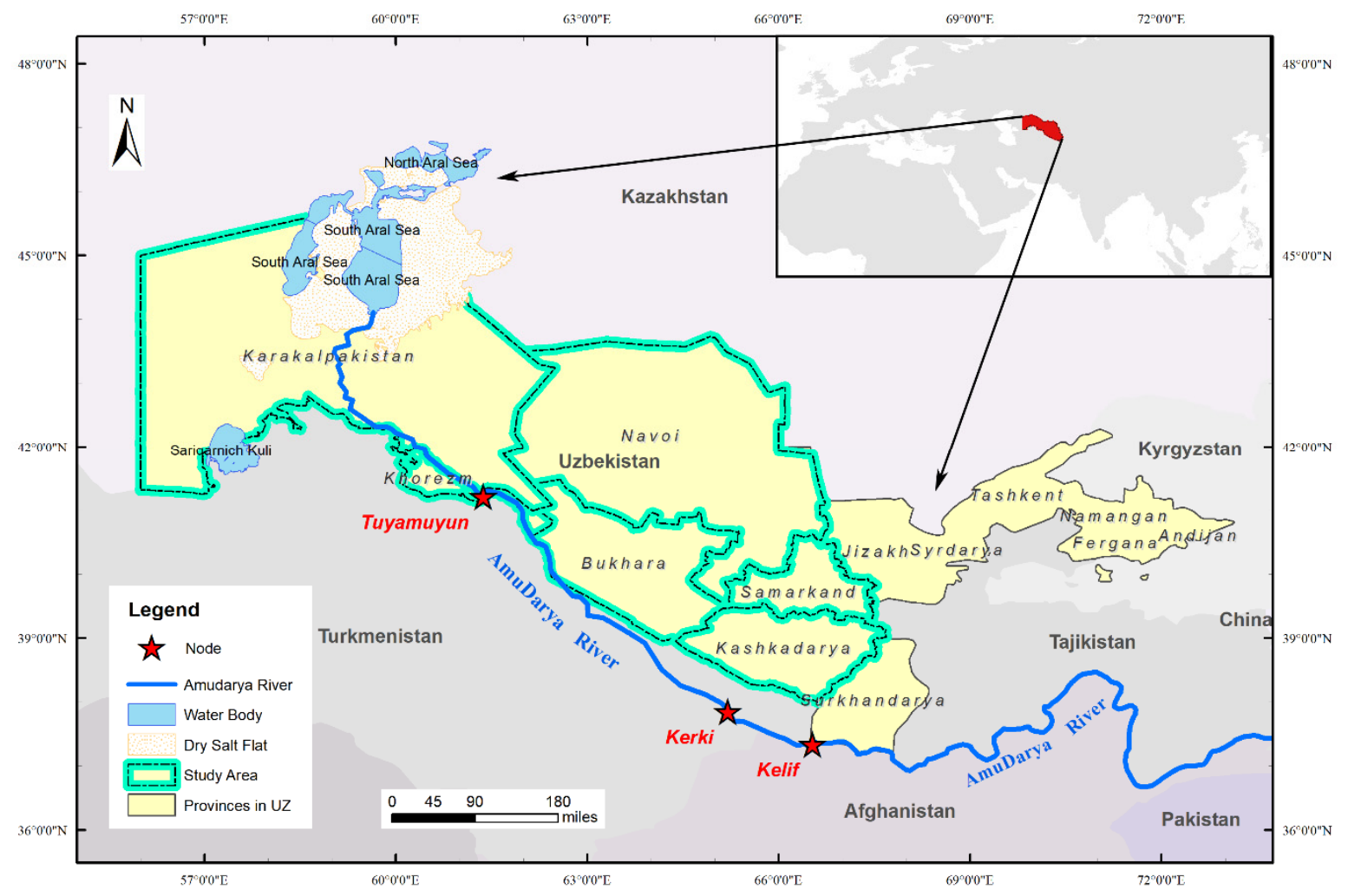

Figure 1. Study area.

Based on its morphological and geographic characteristics, the Amudarya River is divided into three reaches: the upper (upstream of the Kelif gauging station border between Turkmenistan and Uzbekistan), middle (between the Kelif and Tuyamuyun gauging stations), and lower (downstream of the Tuyamuyun gauging station) reaches (CA Water Info). Considering the current feasibility and future compatibility, this study chooses the middle and lower reaches of the Amudarya River as the main research object for the water allocation work in Uzbekistan. As can be seen from the above graphic, six provinces in Uzbekistan are affected, and of them, Karakakpakstan is strictly an autonomous republic, and the province of Surkhandarya is excluded because it is subject to different water intake rules and is mainly supplied by the Surkhandarya River and the upper reach of Amudarya River. The Amudarya River Basin has a complex irrigation system, and from Kelif to the Aral Sea, there are approximately 34 intake channels and 20 collectors, within which the most influential channels are Karakum Canal, Karshi Canal, and Amubukhara Canal.

According to the water system scheme made by the BWO "Amudarya" structure, which includes rivers, reservoirs, water stations, water intakes, and collectors, the scheme of the water system in the study area is depicted in Figure 2. As shown, there are three main water supply sources, the middle and downstream reaches of the Amudarya River, the Zerafshan River (excluding the portion to Tajikstan), and the Kashkadarya River (which is totally used by Uzbekistan). The water supply from the Amudarya River consists of two 
main parts, the intakes from Karshi Canal and the half of the incoming river flow at Kerki station. The former one is based on the fact that the Karshi Canal upstream of the Kerki station in Amudarya River delivers water to Kashkadarya province, which is within the study area and is also affected by the other two rivers. The latter one is based on a watersharing agreement that has so far been widely accepted and implemented by Uzbekistan and Turkmenistan. The bilateral agreement signed by Turkmenistan and Uzbekistan on 15 January 1996 stipulates the quota principle that the "flow of the Amudarya River at Kerki gauging station is divided into equal shares $(50 / 50)$ ". Correspondingly, water users in the study area refer to five sectors (irrigation, livestock, industry, municipality, and ecology) in six provinces (Kashkadarya, Samarkand, Navoiy, Bukhara, Khorezm, and Karakalpakstan). For brevity, the letters A, B, C, D, E, and F are used later to replace Kashkadarya, Samarkand, Navoiy, Bukhara, Khorezm, and Karakalpakstan, respectively.

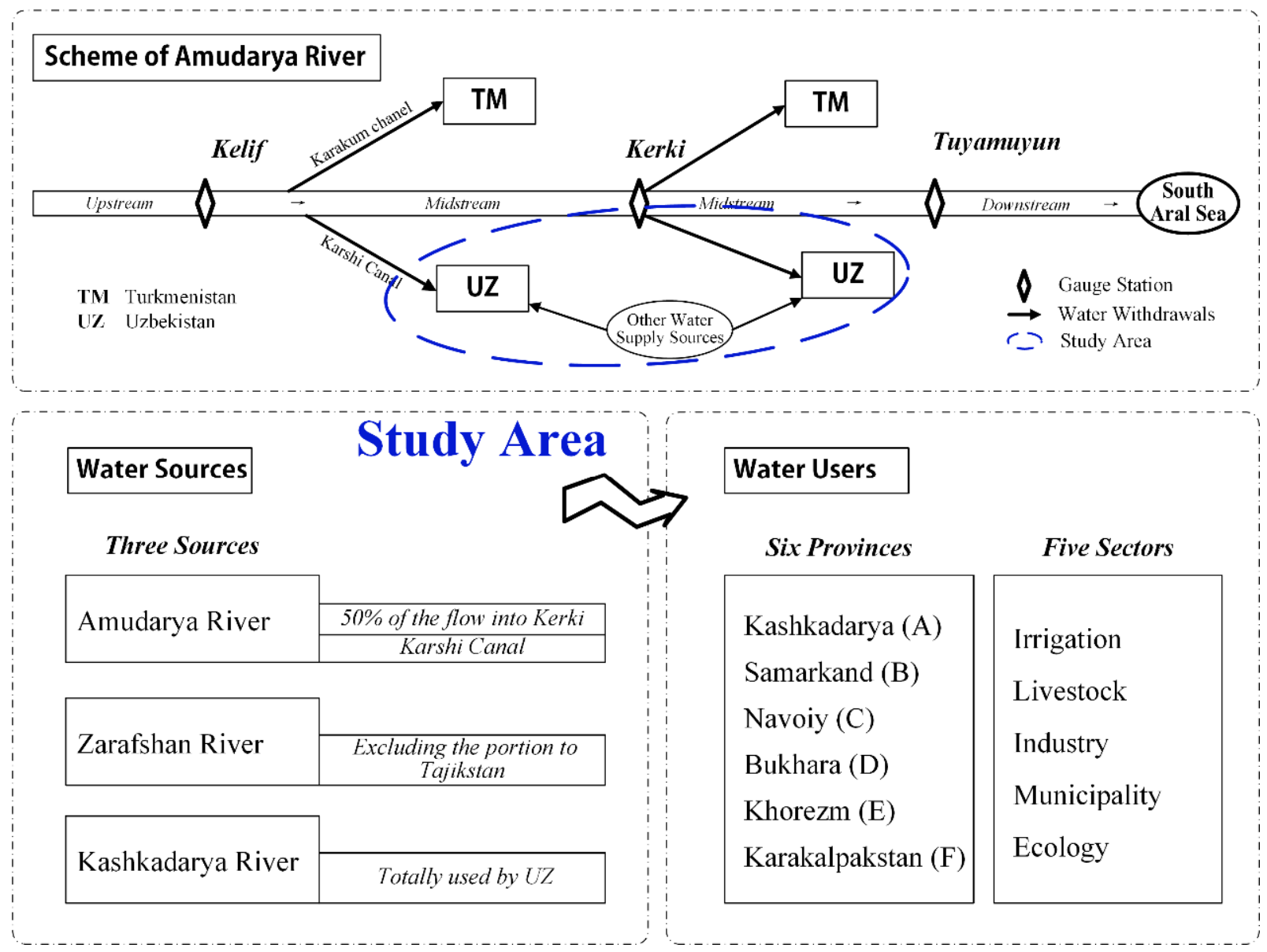

Figure 2. Scheme of the water system in the study area.

\section{Data and Methods}

\subsection{Data Collection}

The hydrological data are from Institute for Irrigation and Water Issues in Uzbekistan, including yearly observed discharge (streamflow) data of Kerki station from 1950-2015 and yearly water intake data of Karshi Canal from 1992-2016; actual and potential (cropspecific) evapotranspiration of crops in Uzbekistan in 2010 are from the Water Use Efficiency Monitor in Central Asia (WUEMoCA: http:/ / wuemoca.net/app/ accessed on 28 March 2019); land use data in study area in the year of 2010, which are derived from Landsat TM remote sensing images and produced by software of eCognition, and the runoff of Kashkadarya River and Zarafshan River at different guaranteed rates, are from Xinjiang 
Institute of Ecology and Geography; socio-economic statistical data, including productivity and actual water use in economic sectors by administrative territories in Uzbekistan for 2010, population, and number of livestock in Uzbekistan, are from the State Committee of the Republic of Uzbekistan on Statistics (https:/ /stat.uz/ accessed on 21 September 2020). Other data, such as land surface evapotranspiration (ET) of different land types in the study area for the years 2003 and 2010 [23], equivalent coefficient value data of ecosystem services (ESV) by land cover [24], and water consumption norm data for livestock (4-12 L/head/day for sheep, 100.25-119 for cow, and 34-49 for cattle) (FAO, 2018) and humans (90-120 L/capita/day) (ADB project 46135-004, 2006), come from other literature and publications. The details are listed in Table 1. Of them, ET, IIWIU, XIEG, WUEMoCA, and UZSTAT are abbreviations for evapotranspiration, Institute for Irrigation and Water Issues in Uzbekistan, Xinjiang Institute of Ecology and Geography, Water Use Efficiency Monitor in Central Asia, and the State Committee of the Republic of Uzbekistan on Statistics.

Table 1. List of data collection.

\begin{tabular}{|c|c|c|c|}
\hline Data & Period & Resolution & Source \\
\hline \multicolumn{4}{|c|}{ Hydrological data } \\
\hline Runoff at Kerki station & 1950-2017 & Yearly & IIWIU \\
\hline Diversion of Karshi Canal & 1992-2016 & Yearly & IIWIU \\
\hline $\begin{array}{c}\text { Runoff of Kashkadarya River and } \\
\text { Zarafshan River }\end{array}$ & - & $\begin{array}{l}\text { At different guaranteed } \\
\text { rates }\end{array}$ & IIWIU \\
\hline \multicolumn{4}{|c|}{ Remote sensing data } \\
\hline Actual ET & 2010 & Crop-specific & WUEMoCA \\
\hline Potential ET & 2010 & Crop-specific & WUEMoCA \\
\hline Land use data & 2010 & & XIEG \\
\hline Actual ET & $2003 / 2010$ & By land type & Ruan H.W. and Yu J.J., 2019 \\
\hline \multicolumn{4}{|c|}{ Socio-economic statistical data } \\
\hline Productivity & 2010 & Province scale & UZSTAT \\
\hline Actual water use & 2010 & Province scale & UZSTAT \\
\hline Population & 2010 & Province scale & UZSTAT \\
\hline Number of livestock & 2011-2018 & Province scale & UZSTAT \\
\hline \multicolumn{4}{|c|}{ Other data } \\
\hline Ecosystem services (ESV) & - & By land type & Li J, Chen H, et al., 2019 \\
\hline Water consumption norm data for livestock & - & - & FAO, 2018 \\
\hline Water consumption norm data for humans & - & - & ADB project 46135-004, 2006 \\
\hline
\end{tabular}

\subsection{ITSP Method}

The purpose of this study is to measure the distribution of water in each water use sector of the study area from an economic point of view at a provincial level and to give the final optimal water allocation schemes, as advice to local water policymakers. In the segment of the optimal allocation of available water, the inexact two-stage stochastic programming (ITSP) model was used, which was proposed by Huang and Loucks (2000) [25]. As linear stochastic programming, the ITSP method has already been widely applied and extended [26-31], and has proven to be effective in dealing with uncertainties in water resource allocation work and in achieving the goal of maximization of economic benefits. When actually making water policy, managers can hardly set deterministic targets and related parameters, because the uncertainties are inevitable in the process of optimization [32-34]. Uncertainty is defined as the phenomenon that some or all of the optimization problem's parameters are not known at the time the problem has to be solved [35]. In this study, the ITSP method deals with uncertainties mainly by two approaches, one of which is to model the parameters conforming to a specific probability distribution known by decision-makers [36], such as the water supply, and another is to express the uncertain 
information as interval values with unknown distribution functions [37]. On the other hand, when seeking to maximize the net economic benefits of the whole water system, monetizing all water users, particularly the ecological sector, allows for an even-handed comparison among them and converts a complex multi-objective management problem into a simpler single-objective economic problem. Thus, by this method, this study is expected to obtain the water allocation schemes with interval values among different sectors and different provinces under different incoming water inflow levels.

The specific optimization model is as follows:

Object:

$$
\operatorname{Max} f^{ \pm}=\sum_{i=1}^{m} \sum_{j=1}^{n} B_{i j}^{ \pm} W_{i j}^{ \pm}-\sum_{i=1}^{m} \sum_{j=1}^{n} \sum_{k=1}^{l} p_{k} C_{i j}^{ \pm} S_{i j k}^{ \pm}
$$

Subject to:

$$
\begin{gathered}
\sum_{i=1}^{m} \sum_{j=1}^{n}\left(W_{i j}^{ \pm}-S_{i j k}^{ \pm}\right) \leq q_{k}^{ \pm}, \quad \forall k \\
S_{i j k}^{ \pm} \leq W_{i j}^{ \pm} \leq W_{i j m a x}^{ \pm}, \quad \forall i, j \\
S_{i j k}^{ \pm} \geq 0, \quad \forall i, j, k
\end{gathered}
$$

where:

- $\quad i=$ water user sector, $i=1,2, \ldots, m$, and $m=5$ (irrigation; livestock; industry; municipality; ecology);

- $\quad j=$ province, $j=1,2, \ldots, n$, and $n=6$ (Kashkadarya; Samarkand; Navoi; Bukhara; Khorezm; Karakalpakstan);

- $\quad k=$ the flow level available, $k=1,2, \ldots, 1$, and $l=5$ (high; high-medium; medium; medium-low; low);

- $f=$ expected net system economic benefit over one year (thousand USD);

- $B_{i j}=$ the net benefit to user $i$ in province $j$ per unit of allocated water (USD $/ 10^{3} \mathrm{~m}^{3}$ );

- $\quad C_{i j}=$ the reduction of net benefit to user $i$ in province $\mathrm{j}$ per unit of water not delivered (USD $/ 10^{3} \mathrm{~m}^{3}$ );

- $\quad W_{i j}=$ the fixed allocation target for water that is promised to user $i$ in province $j$;

- $\quad W_{i j m a x}=$ the water demand for user $i$ in provice $j$;

- $\quad p_{k}=$ the probability of occurrence for different flow levels, and $\sum_{k=1}^{l} p_{k}=1$;

- $q_{k}=$ the water availability under the flow level of $k$;

- $S_{i j k}=$ the amounts by which the water allocation targets $\left(W_{i j}\right)$ are not met when the flows are under the flow level of $k$.

$B_{i j}^{ \pm}, C_{i j}^{ \pm}, W_{i j}^{ \pm}, W_{i j \max }^{ \pm}, q_{k}^{ \pm}$, and $S_{i j k}^{ \pm}$are interval variables. An interval is defined as a number with known upper and lower bounds but an unknown distribution of information.

To make the above model solvable, further work needs to be done. First, let $W_{i j}^{ \pm}=$ $W_{i j}^{-}+\Delta W_{i j} z_{i j}$, where $\Delta W_{i j}=W_{i j}^{+}-W_{i j}^{-}$and $z_{i j} \in[0,1]$; then, $z_{i j}$ are decision variables, instead of $W_{i j}^{ \pm}$, which are used to identify an optimized set of target values. Second, transform the model into two deterministic sub-models, which correspond to the upper and lower bounds of the desired objective function values; namely, $F^{ \pm}$.

The submodel $F^{+}$, which provides the extreme upper bound of system benefit $F_{o p t}^{+}$, can be expressed as follows and gives the solution of $S_{i j k o p t}^{-}$and $z_{i j p o t}$.

Object of submodel $F^{+}$:

$$
\operatorname{Max} F^{+}=\sum_{i=1}^{m} \sum_{j=1}^{n} B_{i j}^{+}\left(W_{i j}^{-}+\Delta W_{i j} z_{i j}\right)-\sum_{i=1}^{m} \sum_{j=1}^{n} \sum_{k=1}^{l} p_{k} C_{i j}^{-} S_{i j k}^{-}
$$

Subject to:

$$
\sum_{i=1}^{m} \sum_{j=1}^{n}\left(W_{i j}^{-}+\Delta W_{i j} z_{i j}-S_{i j k}^{-}\right) \leq q_{k}^{+}, \quad \forall k
$$




$$
\begin{gathered}
S_{i j k}^{-} \leq W_{i j}^{-}+\Delta W_{i j} z_{i j} \leq W_{i j m a x}^{+}, \quad \forall i, j \\
S_{i j k}^{-} \geq 0, \quad \forall i, j, k \\
0 \leq z_{i j} \leq 1, \ldots \forall \mathrm{i}, \mathrm{j}
\end{gathered}
$$

The submodel $F^{-}$, which provides the lower bound of system benefit $F_{o p t}^{-}$, can be expressed as follows and gives the solution of $S_{i j k o p t}^{+}$and $z_{i j p o t}$.

Object of submodel $F^{-}$:

$$
\operatorname{Max} F^{-}=\sum_{i=1}^{m} \sum_{j=1}^{n} B_{i j}^{-}\left(W_{i j}^{-}+\Delta W_{i j} z_{i j}\right)-\sum_{i=1}^{m} \sum_{j=1}^{n} \sum_{k=1}^{l} p_{k} C_{i j}^{+} S_{i j k}^{+}
$$

Subject to:

$$
\begin{gathered}
\sum_{i=1}^{m} \sum_{j=1}^{n}\left(W_{i j}^{-}+\Delta W_{i j} z_{i j}-S_{i j k}^{+}\right) \leq q_{k}^{-}, \quad \forall k \\
S_{i j k}^{+} \leq W_{i j}^{-}+\Delta W_{i j} z_{i j} \leq W_{i j m a x}^{-}, \quad \forall i, j \\
S_{i j k}^{+} \geq 0, \quad \forall i, j, k \\
0 \leq z_{i j} \leq 1, \ldots \forall \mathrm{i}, \mathrm{j}
\end{gathered}
$$

Thus, we have all the solutions under the optimized water allocation targets as follows: $F_{o p t}^{ \pm}=\left[F_{o p t}^{-}, F_{o p t}^{+}\right], S_{o p t}^{ \pm}=\left[S_{i j k o p t}^{-}, S_{i j k o p t}^{+}\right]$and the actual water allocation scheme $A_{i j k o p t}^{ \pm}=W_{i j k o p t}^{ \pm}-S_{i j k o p t}^{ \pm}, A_{i j o p t}^{ \pm}=\sum_{k=1}^{l} p_{k} A_{i j k o p t}^{ \pm}$.

\section{Preparation of Input Data}

\subsection{Water Supply and Water Demand}

According to the above, there are three water supply sources (Amudarya River, Zarafshan River, and Kashkadarya River) and thirty water users (five sectors and six provinces). For the calculation of the water supply and water demand corresponding to the above water suppliers and water users, different related methods were used.

Water availability $\left(q_{k}^{ \pm}\right)$under different incoming flow levels can be obtained based on the hydrologic frequency analysis of water suppliers. The probability distribution for water supply from Amudarya River, which is equal to the sum of fifty percent streamflow of Kerki station plus the water intakes from Karshi Canal, was calculated by the curve-fitting method, which extends the empirical frequency curve with the help of the theoretical frequency curve. The theoretical frequency distribution of Pearson type III distribution (a three-parameter gamma distribution) was selected, and the coefficient of skewness was estimated by visual estimation. The specific frequency diagram and related parameters, including sample size $(n)$, the average value(a), coefficient of variation $(\mathrm{Cv})$, coefficient of skewness(Cs), and guarantee rates(P), are shown in Figure 3 and Tables 2 and 3 . As for the other two water supply sources (Zarafshan River and Kashikadarya River), the amount of water at the guaranteed rates of $50 \%, 75 \%$, and $95 \%$ already exists, and the hydrological analogy method was used to get the results of other guaranteed rates. As shown in Table 3, water supply under five different probabilities $(5 \%, 25 \%, 50 \%, 75 \%$, and $95 \%)\left(q_{k}\right)$ was obtained, and of three water supply sources, the water from Amudarya River takes up the largest percentage of nearly $80 \%$. Under a $50 \%$ probability, the water supply values from the Amudarya River, the Zarafshan River, and the Kashkadarya River amount to $26.06,5.09$, and $1.24 \mathrm{~km}^{3}$, respectively, for a total of $32.40 \mathrm{~km}^{3}$. 


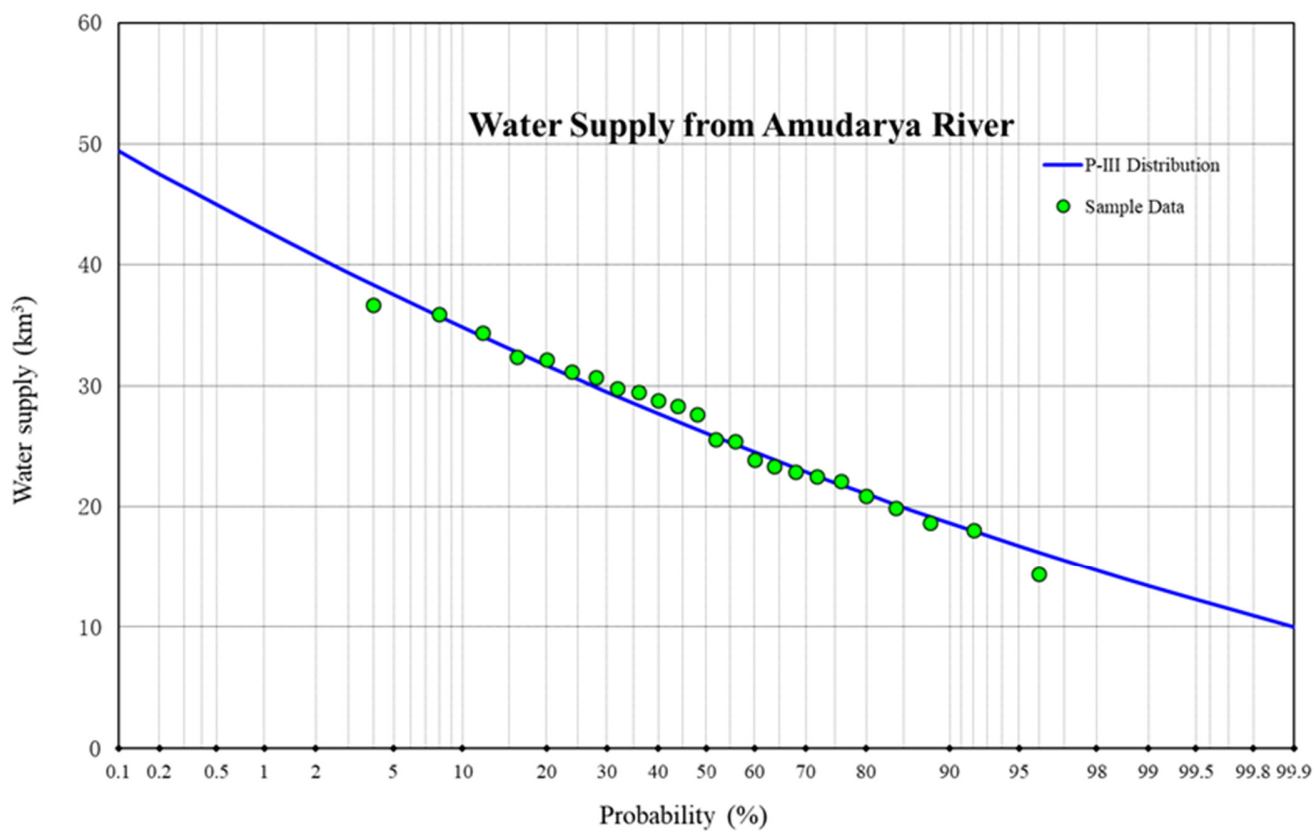

Figure 3. The frequency distribution of water supply from Amudarya River.

Table 2. Statistical parameters of P-III distribution of water supply from Amudarya River.

\begin{tabular}{ccccc}
\hline & $n$ & $\mathbf{a}\left(\mathbf{k m}^{\mathbf{3}}\right)$ & $\mathbf{C v}$ & $\mathbf{C s} / \mathbf{C v}$ \\
\hline Amudarya River & 24 & 26.46 & 0.24 & 1.5 \\
\hline
\end{tabular}

Table 3. Water supply under different guaranteed rates.

\begin{tabular}{cccccc}
\hline Unit: $\mathbf{~ k m}^{\mathbf{3}}$ & $\mathbf{5 \%}$ & $\mathbf{2 5 \%}$ & $\mathbf{5 0 \%}$ & $\mathbf{7 5 \%}$ & $\mathbf{9 5 \%}$ \\
\hline Amudarya River & 37.52 & 30.52 & 26.06 & 21.97 & 16.73 \\
Zarafshan River & 7.84 & 6.38 & 5.09 & 4.29 & 3.96 \\
Kashkadarya River & 1.76 & 1.44 & 1.24 & 1.03 & 0.78 \\
sum & 47.13 & 38.34 & 32.40 & 27.29 & 21.47 \\
\hline
\end{tabular}

After the determination of the random variable $q_{k}$, the discrete variable $q_{k}^{ \pm}$of water supply under five different incoming flow levels were calculated. The frequency distribution of water supply from Amudarya River was divided at probabilities of $20 \%, 40 \%, 60 \%$, and $90 \%$, by considering that the empirical incoming water quantity is divided equally into five parts, and also the theoretical probability interval of medium incoming water level covers the probability of $50 \%$, as far as possible. Then, the five probability intervals of water supply from Amudarya River were obtained, and those of water supply from the other two rivers were obtained by analogy method (Table 4). In Table 4, H, H-M, M, M-L, and L represent five different incoming flow levels of high, high-medium, medium, medium-low, and low. The sum of probabilities under five incoming flow levels equals $100 \%$.

Table 4. Five probability intervals of water supply in study area.

\begin{tabular}{cccccc}
\hline Unit: $\mathbf{k m}^{\mathbf{3}}$ & $\mathbf{H}$ & $\mathbf{H}-\mathbf{M}$ & $\mathbf{M}$ & M-L & L \\
\hline Amudarya River & $(31.66,36.65)$ & $(27.69,31.66)$ & $(24.51,27.69)$ & $(18.62,24.51)$ & $(14.37,18.62)$ \\
Zarafshan River & $(6.62,7.67)$ & $(5.79,6.62)$ & $(5.13,5.79)$ & $(3.89,5.13)$ & $(3.01,3.89)$ \\
Kashkadarya River & $(1.49,1.72)$ & $(1.30,1.49)$ & $(1.15,1.30)$ & $(0.88,1.15)$ & $(0.68,0.88)$ \\
Sum & $(39.77,46.04)$ & $(34.78,39.77)$ & $(30.79,34.78)$ & $(23.39,30.79)$ & $(18.05,23.39)$ \\
Probability & 0.20 & 0.20 & 0.20 & 0.30 & 0.10 \\
\hline
\end{tabular}


Water demand $\left(W_{i j \max }^{ \pm}\right)$for thirty water users (five sectors and six provinces) was calculated mainly by the water quota method (Table 5), except for water users in the sector of industry. The water quota method can be expressed by the following formula: $\Sigma\left(\right.$ Quota $\left.^{ \pm} \times A\right)$. Quota ${ }^{ \pm}$means that water quota for different water use sectors would be intervals, and $A$ represents area or population. The calculation of industrial water demand is based on historical water use data. Table 6 shows the specific values of water demand in each water user. Water demand differs in different water use sectors and provinces, with the sectors of livestock, industry, and municipality needing much less water than the sectors of irrigation and ecology. The average water demand of the irrigation, livestock, industry, municipality, and ecology sectors amounts to 23.856, 0.137, 0.517, 0.453, and $17.976 \mathrm{~km}^{3}$, respectively, and the demand in provinces of A, B, C, D, E, and F amounts to $11.010,6.704,3.313,3.265,3.071$, and $15.575 \mathrm{~km}^{3}$, respectively. It can be seen that $\mathrm{A}$ and $\mathrm{F}$ need more water than other provinces, with irrigation and ecology accounting for the main part of water demand, because A has the largest cropland of 1,056,400 ha and F has the largest forestland, grassland, and waterbodies.

Table 5. Associated data for the calculation of water demand.

\begin{tabular}{ccc}
\hline & Quota & A \\
\hline Irrigation & Actual ET and Potential ET by crop as the interval boundaries & Irrigated area \\
Livestock & Water consumption norm data for sheep, cow, and cattle & Number of livestock \\
Municipality & Water consumption norm data for humans & Population \\
Ecology & Actual ET by land type of the year 2003 and 2010 & Area \\
\hline
\end{tabular}

Table 6. The water demand in different water sectors in different states (unit: million $\mathrm{m}^{3}$ ).

\begin{tabular}{cccc}
\hline & Irrigation & Livestock & Industry \\
\hline A & $(6194.18,8298.91)$ & $(22.67,33.38)$ & $(84.90,93.60)$ \\
\hline B & $(4339.22,5215.88)$ & $(27.63,39.11)$ & $(79.58,81.20)$ \\
\hline C & $(1497.41,1795.77)$ & $(11.44,21.36)$ & $(272.30,290.00)$ \\
\hline D & $(2104.21,2447.68)$ & $(17.33,25.79)$ & $(31.40,35.47)$ \\
\hline E & $(2682.46,2958.18)$ & $(14.76,19.25)$ & $(1.88,2.36)$ \\
\hline F & $(4709.18,5470.01)$ & $(17.01,23.66)$ & $(31.00,31.04)$ \\
\hline sum & $(21,526.66,26,186.44)$ & $(110.84,162.55)$ & $(501.06,533.67)$ \\
\hline A & Municipality & Ecology & Sum \\
\hline B & $(89.45,119.26)$ & $(3486.68,3596.36)$ & $(9877.87,12,141.52)$ \\
\hline C & $(107.45,143.26)$ & $(1660.50,1713.95)$ & $(6214.38,7193.40)$ \\
\hline D & $(28.68,38.24)$ & $(1310.89,1361.85)$ & $(3120.72,3507.22)$ \\
\hline E & $(55.31,73.75)$ & $(858.05,882.46)$ & $(3066.30,3465.15)$ \\
\hline F & $(52.60,70.13)$ & $(167.34,174.40)$ & $(2919.04,3224.31)$ \\
\hline sum & $(55.22,73.62)$ & $(10,164.74,10,575.01)$ & $(14,977.14,16,173.34)$ \\
\hline & $(388.70,518.26)$ & $(17,648.19,18,304.02)$ & $(40,175.44,45,704.94)$ \\
\hline
\end{tabular}

\subsection{Coefficient of Economic Benefit and Economic Penalty}

As input data for the optimization model, the economic benefit coefficient and the penalty coefficient have been calculated with a unit of USD $/ 10^{3} \mathrm{~m}^{3}$. The former coefficient is the net benefit produced by a unit of water when the given quantity of water has been delivered, as expressed by $B_{i j}^{ \pm}$, and the latter coefficient is the net penalty on the economy when promised water is not delivered, which may cause an increase in water costs, as expressed by $C_{i j}^{ \pm}$with the same unit as $B_{i j}^{ \pm}$. The method of comparing output value with 
actual water consumption was used to calculate the economic benefit coefficients and economic penalty coefficients of water use sectors of irrigation, livestock, industry, and municipality, and the computation of the coefficients in the sector of ecology is based on ecosystem service value (ESV).

As shown in Table 7, the economic benefit values of sectors are ranked from high to low by industry, livestock, municipality, irrigation, and ecology. The livestock and industry sectors have the highest benefit values, with an average of $34,161 \mathrm{USD} / 10^{3} \mathrm{~m}^{3}$ and $49,726 \mathrm{USD} / 10^{3} \mathrm{~m}^{3}$, and the ecology and irrigation sectors have the lowest values, with an average of $104 \mathrm{USD} / 10^{3} \mathrm{~m}^{3}$ and $205 \mathrm{USD} / 10^{3} \mathrm{~m}^{3}$. The distribution of the economic benefit values of the industry sector in different provinces varies greatly, compared to other sectors. In the irrigation and livestock sectors, values in $\mathrm{F}$ are much lower than in other provinces, mainly because of their higher agricultural production costs and lower irrigation efficiency. By province, E has the highest value of $47,670 \mathrm{USD} / 10^{3} \mathrm{~m}^{3}$, and $\mathrm{F}$ has the lowest value of $6720 \mathrm{USD} / 10^{3} \mathrm{~m}^{3}$. The situation is similar for the penalty coefficient, which can be seen in Table 8.

Table 7. The economic benefit coefficient.

\begin{tabular}{ccccccc}
\hline $\mathbf{\$} / \mathbf{1 0}^{\mathbf{3}} \mathbf{~ m}^{\mathbf{3}}$ & Irrigation & Livestock & Industry & Municipality & Ecology & Average \\
\hline A & $(125,138)$ & $(36,963,39,306)$ & $(32,105,36,792)$ & $(2790,2929)$ & $(45,46)$ & $15,123.90$ \\
B & $(526,539)$ & $(38,530,44,599)$ & $(15,606,15,721)$ & $(21,887,22,143)$ & $(36,37)$ & $15,962.33$ \\
C & $(183,210)$ & $(32,823,34,031)$ & $(8775,9848)$ & $(20,185,25,231)$ & $(112,112)$ & $13,151.02$ \\
D & $(178,206)$ & $(35,777,38,217)$ & $(33,609,54,185)$ & $(4671,4677)$ & $(137,139)$ & $14,735.28$ \\
E & $(126,153)$ & $(38,200,38,246)$ & $(175,470,210,679)$ & $(6622,6872)$ & $(163,167)$ & $47,669.92$ \\
F & $(35,44)$ & $(16,520,16,725)$ & $(14,171,14,192)$ & $(2581,2673)$ & $(128,129)$ & 6719.71 \\
Average & 205.29 & $34,161.39$ & $49,725.79$ & $10,271.86$ & 104.13 & - \\
\hline
\end{tabular}

Table 8. The economic penalty coefficient.

\begin{tabular}{ccccccc}
\hline$\$ \mathbf{1} \mathbf{1}^{\mathbf{3}} \mathbf{~}^{\mathbf{3}}$ & Irrigation & Livestock & Industry & Municipality & Ecology & Average \\
\hline A & $(147,158)$ & $(42,711,45,761)$ & $(38,582,41,338)$ & $(3203,3432)$ & $(51,54)$ & $17,543.72$ \\
B & $(596,639)$ & $(46,552,49,878)$ & $(17,543,18,796)$ & $(24,657,26,418)$ & $(40,43)$ & $18,516.30$ \\
C & $(220,236)$ & $(37,438,40,112)$ & $(10,429,11,174)$ & $(25,433,27,250)$ & $(126,135)$ & $15,255.18$ \\
D & $(215,231)$ & $(41,436,44,396)$ & $(35,477,38,011)$ & $(5235,5609)$ & $(155,166)$ & $17,092.92$ \\
E & $(156,168)$ & $(42,810,45,868)$ & $(216,243,231,689)$ & $(7557,8097)$ & $(185,198)$ & $55,297.11$ \\
F & $(44,47)$ & $(18,617,19,947)$ & $(15,883,17,018)$ & $(2942,3153)$ & $(144,154)$ & 7794.87 \\
Average & 238.14 & $39,627.21$ & $57,681.92$ & $11,915.36$ & 120.79 & - \\
\hline
\end{tabular}

\section{Results}

\subsection{Water Shortage by Supply-Demand Balance Analysis}

Supply-demand balance analysis can be done based on the above calculations of water supply and water demand. The total sum of the water demand amounts to $40.173-45.704 \mathrm{~km}^{3}$, which exceeds the water supply under all incoming flow levels and under most guaranteed rates, and thus, water shortage exists and optimal allocation work is necessary. By the difference between water supply under different guaranteed rates and water demand intervals, the specific values of water shortage under different probabilities are shown in Table 9, expressed respectively in percentage terms and actual water quantity, and it includes both interval values and mean values. At a guaranteed rate of $5 \%$, there is no shortage; however, there are varying degrees of water shortage under other guaranteed rates of $25 \%, 50 \%, 75 \%$, and $95 \%$. When under the guaranteed rate of $50 \%$, there is an average water shortage of $10.542 \mathrm{~km}^{3}$, and an average water shortage ratio of $24.24 \%$. The second type of water shortage under different incoming flow levels can also be obtained by the difference between water supply under different levels and an average value of the total interval value of water demand (Table 10). Considering the probability of each 
incoming flow level, the weighted average interval values of water shortage and water shortage ratio were obtained, which are $7.863-13.047 \mathrm{~km}^{3}$ and $18.31-30.38 \%$, respectively.

Table 9. Water shortage (Type I) under different guaranteed rates.

\begin{tabular}{cccccc}
\hline & $\mathbf{5 \%}$ & $\mathbf{2 5 \%}$ & $\mathbf{5 0 \%}$ & $\mathbf{7 5 \%}$ & $\mathbf{9 5 \%}$ \\
\hline Water shortage $\left(\mathrm{km}^{3}\right)$ & 0 & $(1.83,7.37)$ & $(7.78,13.31)$ & $(12.88,18.41)$ & $(18.70,24.23)$ \\
Average $\left(\mathrm{km}^{3}\right)$ & 0 & 4.60 & 10.54 & 15.64 & 21.47 \\
Water shortage ratio $(\%)$ & 0 & $(4.57,16.12)$ & $(19.36,29.12)$ & $(32.06,40.28)$ & $(46.56,53.02)$ \\
Average $(\%)$ & 0 & 10.34 & 24.24 & 36.17 & 49.79 \\
\hline
\end{tabular}

Table 10. Water shortage (Type II) under different incoming flow levels.

\begin{tabular}{|c|c|c|c|c|c|c|}
\hline & $\mathbf{H}$ & H-M & $\mathbf{M}$ & M-L & $\mathbf{L}$ & Weighted Average \\
\hline Water shortage $\left(\mathrm{km}^{3}\right)$ & $(0,3.16)$ & $(3.16,8.16)$ & $(8.16,12.15)$ & $(12.15,19.55)$ & $(19.55,24.89)$ & $(7.86,13.05)$ \\
\hline Water shortage ratio (\%) & $(0,7.37)$ & $(7.37,19.00)$ & $(19.00,28.29)$ & $(28.29,45.52)$ & $(45.52,57.97)$ & $(18.31,30.38)$ \\
\hline
\end{tabular}

\subsection{Water Allocation Schemes under Maximization of Economic Benefits}

The net system economic benefits obtained the interval results of 25.066-27.856 $\left(10^{9}\right.$ USD) in this model for the maximization of economic benefits. In Table 11, the feature of the optimal water allocation $\left(A_{i j o p t}^{ \pm}\right)$is given, which was determined by the two decision variables of the optimal water allocation target value $\left(W_{i j o p t}^{ \pm}\right)$and the water shortage not meeting the target value $\left(S_{i j o p t}^{ \pm}\right)$. "Upper" means deterministic value, contrary to intervals, and the decision variables of water allocation reach the highest value of water demand. Most optimal water allocation variables related to the irrigation and ecology users would be intervals, while those related to livestock, industrial, and municipality water users would be deterministic values as a result of no water deficits and total satisfaction with the upper bound of the water demand. Water allocation scheme in sectors of livestock, industrial, and municipality are simpler, with the same decision results and economic benefits, no matter how the incoming flow level changes. For these three sectors, the total volume of water allocation amounts to 1214.48 million $\mathrm{m}^{3}$, the total value of economic benefits amounts to $19.593-21.847$ ( $\left.10^{9} \mathrm{USD}\right)$, and their respective percentages of the total value are $3.71 \%$ and $77.04 \%$. The specific values of water allocation and economic benefits and their percentages for three water use sectors in different provinces are shown in Table 12 and Figure $4 a, b$. Province of $C$ receives the most water because of large industrial water requirements, with the highest share of these three sectors in all water use sectors $(12.48 \%)$, and provides the highest percentages of benefits $(91.19 \%)$ compared with other sectors. However, the province of $\mathrm{F}$ receives the lowest share of water $(1.55 \%)$ and provides the lowest share of benefits $(54.00 \%)$.

Table 11. Feature of water allocation values.

\begin{tabular}{cccccc}
\hline & Irrigation & Livestock & Industry & Municipality & Ecology \\
\hline A & interval & upper & upper & upper & interval \\
B & upper & upper & upper & upper & interval \\
C & upper & upper & upper & upper & interval \\
D & upper & upper & upper & upper & upper \\
E & upper & upper & upper & upper & upper \\
F & interval & upper & upper & upper & interval \\
\hline
\end{tabular}


Table 12. Water allocation and economic benefits for three sectors of livestock, industry, and municipality.

\begin{tabular}{ccccc}
\hline & \multicolumn{2}{c}{ Water Allocation } & \multicolumn{2}{c}{ Economic Benefits } \\
\cline { 2 - 5 } & $\mathbf{1 0}^{\mathbf{6}} \mathbf{m}^{\mathbf{3}}$ & $\mathbf{\%}$ & $\mathbf{1 0}^{\mathbf{9}} \mathbf{U S D}$ & $\%$ \\
\hline $\mathrm{A}$ & 246.24 & 2.64 & $(4.57,5.11)$ & 81.78 \\
$\mathrm{~B}$ & 263.57 & 4.66 & $(5.91,6.19)$ & 68.56 \\
$\mathrm{C}$ & 349.60 & 12.48 & $(4.02,4.55)$ & 91.19 \\
$\mathrm{D}$ & 135.01 & 3.90 & $(2.46,3.25)$ & 82.83 \\
$\mathrm{E}$ & 91.74 & 2.85 & $(1.61,1.72)$ & 79.02 \\
F & 128.32 & 1.55 & $(1.02,1.03)$ & 54.00 \\
\hline
\end{tabular}

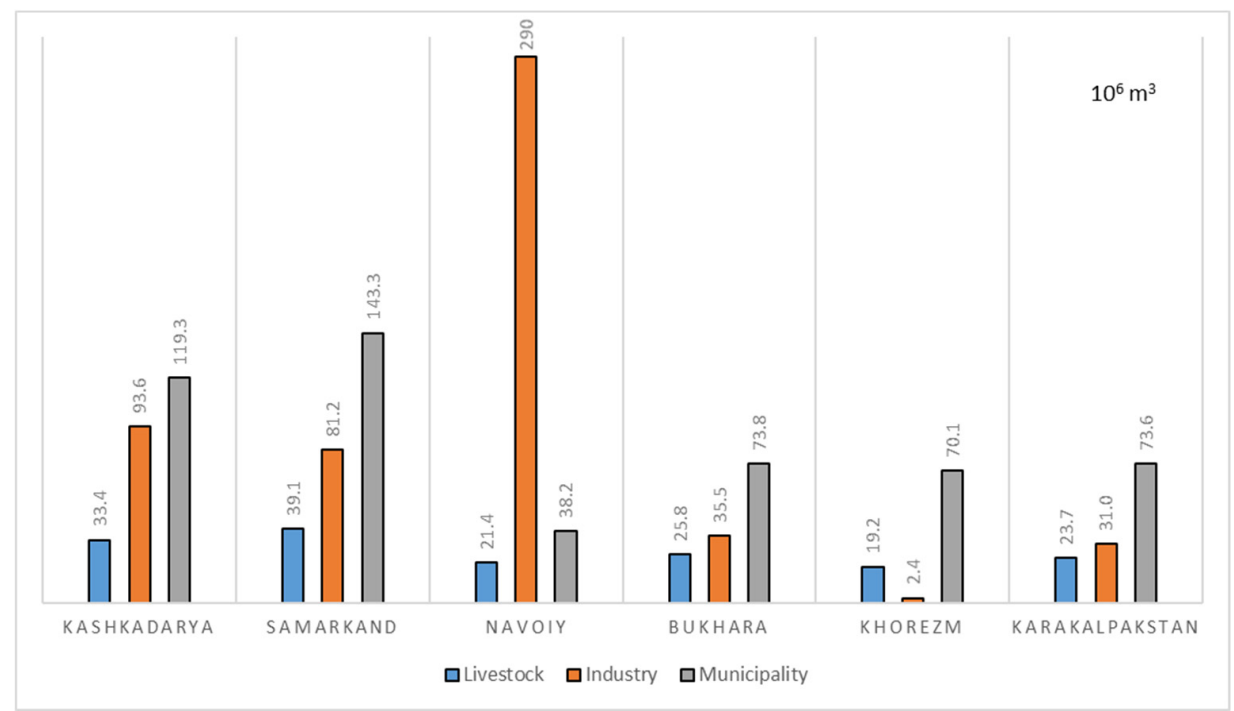

(a)

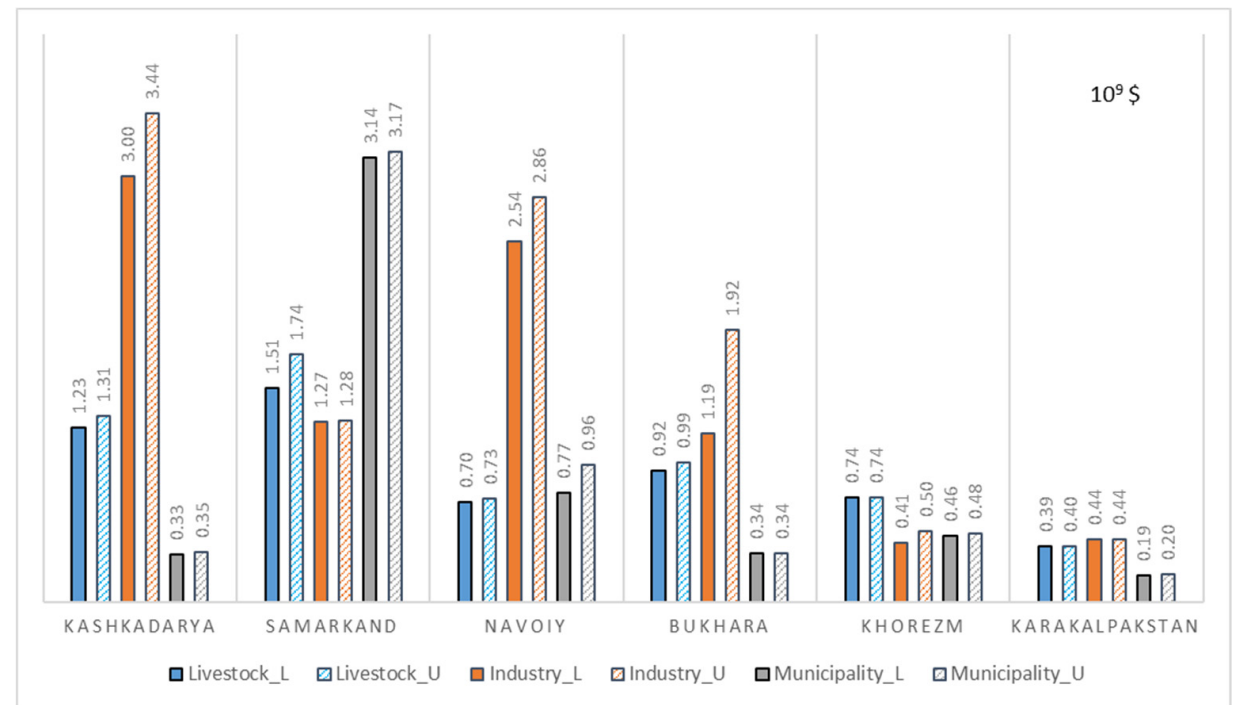

(b)

Figure 4. (a) Water allocation in different provinces for three sectors; (b) economic benefits in different provinces for three sectors.

Water competition under different incoming flow levels mainly occurs in the sectors of irrigation and ecology. On the whole, the total value of water allocation and economic benefits in the sector of irrigation reaches respectively $20.441-22.061 \mathrm{~km}^{3}$ and $4.789-5.348$ $\left(10^{9}\right.$ USD), with the respective proportions of $64.87 \%$ and $18.85 \%$. The water allocation scheme in irrigation among different provinces under different incoming flow levels is 
shown in Table 13, with H, H-M, M, M-L, and L corresponding to high, high-middle, middle, middle-low, and low incoming flow level. Combined with Table 11, provinces of $B, C, D$, and $E$ receive the upper bound of water demand, behaving as certain values, which means they have a higher water allocation priority than other provinces (A and F). These four provinces receive a much higher water distribution in irrigation than other water use sectors, accounting for more than $60 \%$, and provide corresponding benefits less than $20 \%$, except B. In the province of A, water shortage only occurs at the L level, and the optimal target value of water allocation (water demand value with a certain factor) can be satisfied at other levels. The province of $F$ suffers from water shortage at all levels and even receives zero water distribution under $\mathrm{M}, \mathrm{M}-\mathrm{L}$, and $\mathrm{L}$ levels, which can be explained by the extremely low economic benefit per unit of water use in irrigation.

Table 13. Water allocation scheme in the sector of irrigation.

\begin{tabular}{cccccccc}
\hline & \multicolumn{5}{c}{ Irrigation } \\
\hline $\mathbf{k m}^{\mathbf{3}}$ & $\mathbf{H}$ & $\mathbf{H}-\mathbf{M}$ & $\mathbf{M}$ & $\mathbf{M}-\mathbf{L}$ & $\mathbf{L}$ & Water\% & Benefit\% \\
\hline A & $(8.21,8.30)$ & $(8.21,8.30)$ & $(8.21,8.30)$ & $(8.21,8.30)$ & $(3.36,8.30)$ & 85.91 & 17.71 \\
B & 5.22 & 5.22 & 5.22 & 5.22 & 5.22 & 92.30 & 31.47 \\
C & 1.80 & 1.80 & 1.80 & 1.80 & 1.80 & 64.09 & 7.51 \\
D & 2.45 & 2.45 & 2.45 & 2.45 & 2.45 & 70.64 & 13.64 \\
E & 2.96 & 2.96 & 2.96 & 2.96 & 2.96 & 91.75 & 19.62 \\
F & $(1.51,5.47)$ & $(0.00,1.25)$ & 0.00 & 0.00 & 0.00 & 9.92 & 0.37 \\
\hline
\end{tabular}

For the sector of ecology, the total value of water allocation and economic benefits amounts to respectively $8.237-12.354 \mathrm{~km}^{3}$ and $0.821-1.392\left(10^{9} \mathrm{USD}\right)$, with the respective proportions of $31.42 \%$ and $4.11 \%$. Its specific water allocation scheme among different provinces under different incoming flow levels is shown in Table 14. Provinces of D and E meet the greatest demand for ecological water under all incoming flow levels. However, in the other four provinces, water demand for ecology cannot be satisfied, which is manifested in different degrees of water shortage under different incoming water conditions. Of them, $F$ receives relatively higher water allocation priority, and the water shortage occurs only at $\mathrm{M}, \mathrm{M}-\mathrm{L}$, and $\mathrm{L}$ levels. The ecological sector accounts for a huge share of the water allocated to Province F, as high as $88.53 \%$ (the share of the ecological sector in all water-use sectors), and this share is much larger than in other provinces. In order of priority, province $C$ is the next, and it satisfies the lower bound of water demand under $\mathrm{H}$ and $\mathrm{H}-\mathrm{M}$ levels; however, it receives zero values of water under $M-L$ and $L$ levels. Then, to $A$ and $B$, they even suffer from water shortage under $\mathrm{H}$ level, but A can still satisfy the lower bound of water demand under $\mathrm{H}$ level, which is different from $\mathrm{B}$. The province of $\mathrm{B}$ receives zero water distribution from the level of $\mathrm{M}$ and provides a very low share of economic benefits, less than $0 \%$.

Table 14. Water allocation scheme in the sector of ecology.

\begin{tabular}{cccccccc}
\hline & \multicolumn{7}{c}{ Ecology } \\
\hline $\mathbf{k m}^{\mathbf{3}}$ & $\mathbf{H}$ & $\mathbf{H}-\mathbf{M}$ & $\mathbf{M}$ & $\mathbf{M}-\mathbf{L}$ & $\mathbf{L}$ & Water\% & Benefit\% \\
\hline A & $(3.49,3.60)$ & $(0.00,3.60)$ & 0.00 & 0.00 & 0.00 & 11.45 & 0.51 \\
B & $(0.00,1.71)$ & 0.00 & 0.00 & 0.00 & 0.00 & 3.03 & -0.03 \\
C & $(1.31,1.36)$ & $(1.31,1.36)$ & $(0.00,1.22)$ & 0.00 & 0.00 & 23.43 & 1.30 \\
D & 0.88 & 0.88 & 0.88 & 0.88 & 0.88 & 25.47 & 3.53 \\
E & 0.17 & 0.17 & 0.17 & 0.17 & 0.17 & 5.41 & 1.37 \\
F & 10.58 & 10.58 & $(7.90,10.58)$ & $(0.50,7.81)$ & $(0.00,0.40)$ & 88.53 & 45.63 \\
\hline
\end{tabular}

\subsection{Comparison with the Actual Water Allocation Schemes}

In order to see how the optimization model affects the water distribution schemes in the study area, the actual distributed water and economic outputs in the base year 
of 2010 were used for the comparison with the corresponding results after optimization work. Considering the incoming water from Amudarya River (including 50\% streamflow at Kerki station and intakes from Karshi Canal) in 2010 was $32.140 \mathrm{~km}^{3}$, corresponding to the high incoming flow level, thus the water allocation scheme under $\mathrm{H}$ level was selected to perform the comparison. Four sectors of irrigation, livestock, industry, and municipality were considered, but not the sector of Ecology, because related relative quantitative calculations in this sector are difficult. In the process of calculation, some intervals were replaced by mean values. The optimized result of total water allocation in four sectors throughout six provinces amounts to $25.373 \mathrm{~km}^{3}$ and is reduced by $3.706 \mathrm{~km}^{3}$, compared to the actual water use of $29.078 \mathrm{~km}^{3}$. In addition, the optimized result of total economic benefits reaches $25.946\left(10^{9} \mathrm{USD}\right)$, and is increased by $3.885\left(10^{9} \mathrm{USD}\right)$, compared to the actual economic benefits of 22.061 ( $\left.10^{9} \mathrm{USD}\right)$.

The specific values and additions can be seen in Figures 5 and 6 . In these figures, the columns with different colors represent the ups and downs by comparing the actual values with optimized values. Red means rising, green is falling, and yellow is unchanged. In Figure 5, the optimized values increase overall in all provinces in the sector of livestock and industry, separately by $0.026 \mathrm{~km}^{3}$ and by $0.013 \mathrm{~km}^{3}$ in total. In the sectors of irrigation and municipality, there are increases and decreases in different provinces; however, the sum of the whole sector is separately decreased by $3.544 \mathrm{~km}^{3}$ and $0.201 \mathrm{~km}^{3}$. In Figure 6, the variation of economic benefits in different sectors in six provinces is basically consistent with the changing trend of water distribution in Figure 5. The difference is that the total values of the four sectors all have increased separately by $0.712,0.872,0.823$, and $1.478\left(10^{9} \mathrm{USD}\right)$. Generally, in terms of water use and economic benefits, the ups and downs are inconsistent across the four different sectors in each province and across the six different provinces in each sector, while the trend of decreasing total water use and increasing total economic benefits is obvious, which means that the optimization work plays a positive role in the allocation of water resources in the study area.

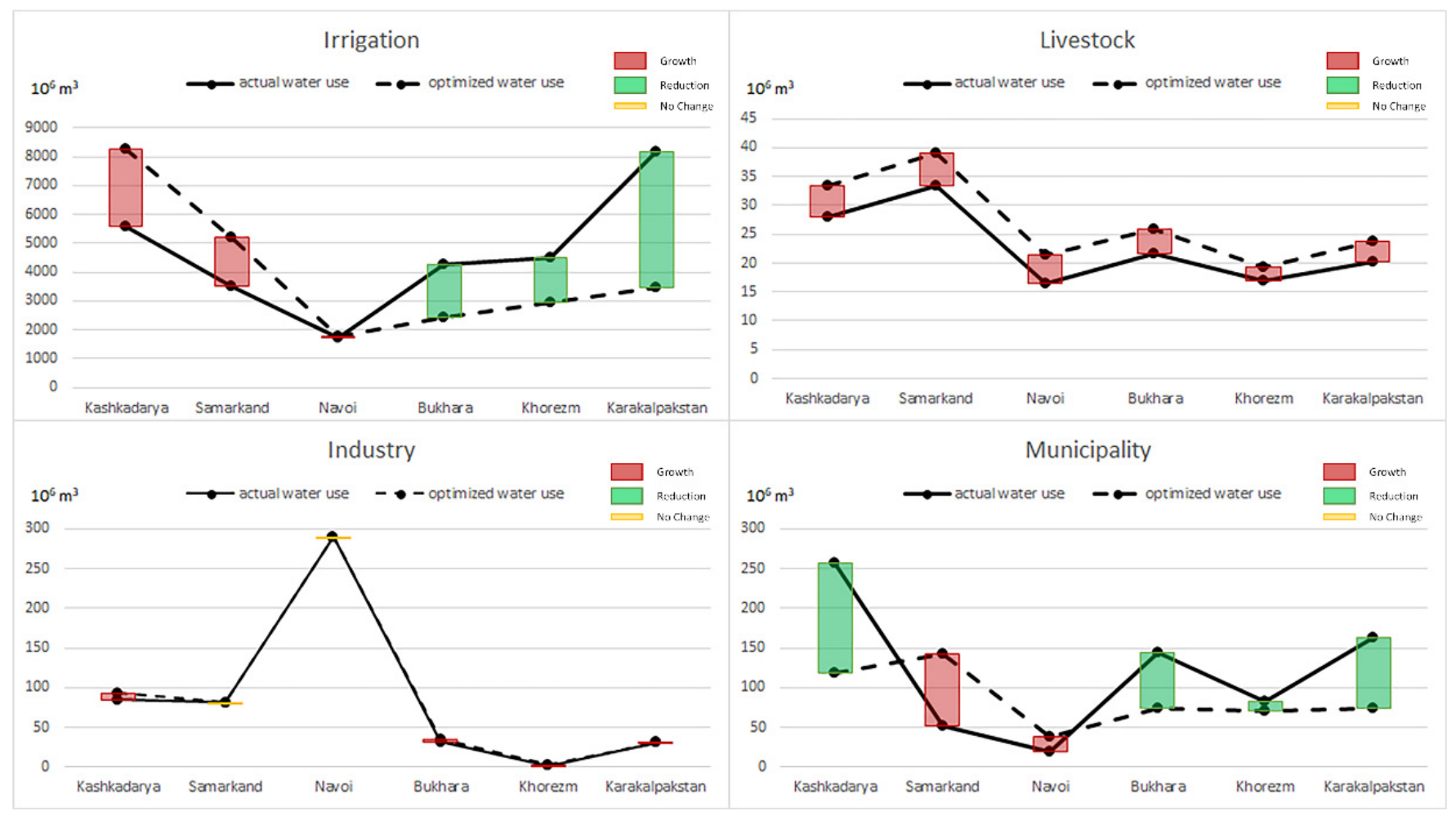

Figure 5. Comparison between actual water use and optimized water use. 


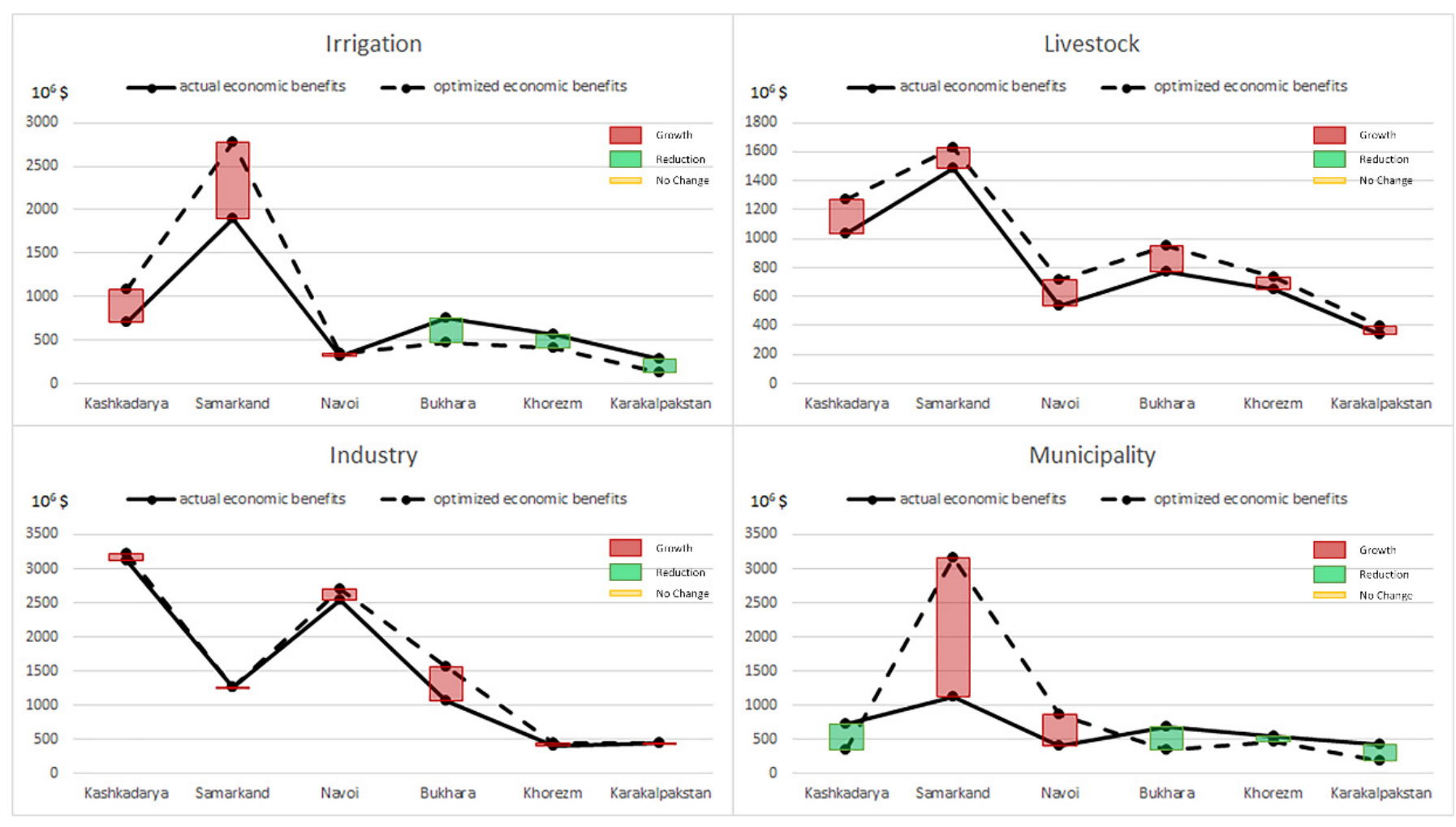

Figure 6. Comparison between actual economic benefits and optimized economic benefits.

\section{Discussion}

\subsection{Optimized Water Distribution among Sectors}

Water allocation is redistributed among the five water use sectors (irrigation, livestock, industry, municipality, and ecology). Under high incoming flow level, water allocation by sector respectively amounts to $22.130-26.186,0.163,0.534,0.518$, and $16.429-18.304 \mathrm{~km}^{3}$, and economic benefits amount to 4.923-5.530, 5.491-5.901, 8.863-10.436, 5.239-5.510, and 1.788-1.894 ( $10^{9}$ USD). Under high-medium incoming flow level, water allocation by sector respectively amounts to $20.624-21.970,0.163,0.534,0.518$, and $12.943-16.590 \mathrm{~km}^{3}$, and economic benefits amount to 4.852-5.344, 5.491-5.901, 8.863-10.436, 5.239-5.510, and $1.599-1.825$ ( $10^{9}$ USD). Under medium incoming flow level, water allocation by sector respectively amounts to 20.624-20.716, 0.163, 0.534, 0.518, and $8.955-12.850 \mathrm{~km}^{3}$, and economic benefits amount to 4.852-5.288, 5.491-5.901, 8.863-10.436, 5.239-5.510, and 1.011-1.625 ( $10^{9}$ USD). Under medium-low incoming flow level, water allocation by sector respectively amounts to $20.624-20.716,0.163,0.534,0.518$, and $1.553-8.862 \mathrm{~km}^{3}$, and economic benefits amount to $4.852-5.288,5.491-5.901,8.863-10.436,5.239-5.510$, and (-0.128)-1.074 (10 $0^{9}$ USD). Under low incoming flow level, water allocation by sector respectively amounts to $15.777-20.716,0.163,0.534,0.518$, and $1.057-1.460 \mathrm{~km}^{3}$, and economic benefits amount to $4.086-5.288,5.491-5.901,8.863-10.436,5.239-5.510$, and $(-0.204)-0.011$ ( $10^{9}$ USD).

By the calculation of the weighted average of the results under different flow levels, the results of water allocation and economic benefits by sector can be seen in Table 15. It is found that the three water use sectors of livestock, industrial, and municipality have the highest water allocation priority, with the lower water distribution(3.71\%, share of all sectors) and higher economic benefits $(77.04 \%$, share of all sectors). The water use competition mainly exists in the other two sectors of irrigation and ecology, with their shares of all sectors in water allocation being $64.87 \%$ and $31.42 \%$, and in economic benefits being $18.85 \%$ and $4.11 \%$. In comparison with the actual water allocation in the base year of 2010, the optimized value of water allocation ( $\mathrm{H}$ level) in the sectors of irrigation and 
municipality respectively increases by $3.544 \mathrm{~km}^{3}$ and $0.201 \mathrm{~km}^{3}$, and in the sector of livestock and industry, it respectively decreases by $0.026 \mathrm{~km}^{3}$ and $0.013 \mathrm{~km}^{3}$; the optimized value of economic benefits in the sectors of irrigation, municipality, livestock, and industry respectively decreases by $0.712,1.478,0.872$, and 0.823 ( $10^{9}$ USD).

Table 15. Water allocation and economic benefits by sector.

\begin{tabular}{cccccc}
\hline & Irrigation & Livestock & Industry & Municipality & Ecology \\
\hline Water allocation $\left(\mathrm{km}^{3}\right)$ & $(20.44,22.06)$ & 0.163 & 0.534 & 0.518 & $(8.24,12.35)$ \\
Percentages $(\%)$ & 64.87 & 0.50 & 1.63 & 1.58 & 31.42 \\
Economic benefits (10 $\mathrm{USD})$ & $(4.79,5.35)$ & $(5.49,5.90)$ & $(8.86,10.44)$ & $(5.24,5.51)$ & $(0.82,1.39)$ \\
Percentages (\%) & 18.85 & 21.18 & 35.88 & 19.98 & 4.11 \\
\hline
\end{tabular}

\subsection{Optimized Water Distribution among Provinces}

Water allocation is redistributed among the six provinces (Kashkadarya, Samarkand, Navoiy, Bukhara, Khorezm, and Karakalpakstan). Under high incoming flow level, water allocation by province respectively amounts to 11.939-12.142, 5.479-7.193, 3.456-3.507, 3.465, 3.224 , and $12.210-16.173 \mathrm{~km}^{3}$, and economic benefits amount to 5.754-6.414, 8.642-9.066, 4.493-5.078, 3.016-3.879, 2.016-2.197, and 2.382-2.636 (109 USD). Under high-medium incoming flow level, water allocation by province respectively amounts to 8.453-12.142, $5.479,3.456-3.507,3.465,3.224$, and $10.703-11.957 \mathrm{~km}^{3}$, and economic benefits amount to 5.566-6.414, 8.642-8.996, 4.493-5.078, 3.016-3.879, 2.016-2.197, and 2.310-2.450 (10 ${ }^{9}$ USD). Under medium incoming flow level, water allocation by province respectively amounts to $8.453-8.545,5.479,2.145-3.364,3.465,3.224$, and $8.026-10.703 \mathrm{~km}^{3}$, and economic benefits amount to 5.566-6.233, 8.642-8.996, 4.316-5.060, 3.016-3.879, 2.016-2.197, and 1.899-2.394 (10 $\$$ ). Under medium-low incoming flow level, water allocation by province respectively amounts to $8.453-8.545,5.479,2.145,3.465,3.224$, and $0.624-7.934 \mathrm{~km}^{3}$, and economic benefits amount to 5.566-6.233, 8.642-8.996, 4.316-4.907, 3.016-3.879, 2.016-2.197, and $0.760-1.997$ ( $\left.10^{9} \mathrm{USD}\right)$. Under low incoming flow level, water allocation by province respectively amounts to $3.606-8.545,5.479,2.145,3.465,3.224$, and $0.128-0.532 \mathrm{~km}^{3}$, and economic benefits amount to 4.800-6.233, 8.642-8.996, 4.316-4.907, 3.016-3.879, 2.016-2.197, and $0.684-0.934$ ( $10^{9}$ USD).

By the calculation of the weighted average of the results under different flow levels, the results of water allocation and economic benefits by province can be seen in Table 16. It is found that, only in the province of D and $\mathrm{E}$, the upper bound of water demand can be satisfied. Province A gets the largest portion of water (28.46\%, share of all provinces), and $\mathrm{F}$ follows (25.32\%, share of all provinces). Province B provides the highest economic benefits with a $32.82 \%$ share, and A provides the second-highest economic benefits with a $22.00 \%$ share. In comparison with the actual water allocation in the base year of 2010, with no consideration of water use in the ecological sector, the optimized value of water allocation ( $\mathrm{H}$ level) in the provinces of $\mathrm{A}, \mathrm{B}$, and $\mathrm{C}$ respectively increases by $2.544 \mathrm{~km}^{3}, 1.797 \mathrm{~km}^{3}$, and $0.111 \mathrm{~km}^{3}$, and in the province of $\mathrm{D}, \mathrm{E}$, and $\mathrm{F}$, it respectively decreases by $1.863 \mathrm{~km}^{3}$, $1.546 \mathrm{~km}^{3}$, and $4.749 \mathrm{~km}^{3}$; the optimized value of economic benefits in the provinces of A, $B, C$, and D respectively increases by $0.350,3.045,0.836$, and 0.066 (10 ${ }^{9}$ USD), and in the provinces of $\mathrm{E}$ and $\mathrm{F}$, it respectively decreases by 0.079 and 0.332 (10 $\mathrm{USD}$ ).

Table 16. Water allocation and economic benefits by province.

\begin{tabular}{ccccccc}
\hline & A & B & C & D & E & F \\
\hline Water allocation $\left(\mathrm{km}^{3}\right)$ & $(8.67,9.98)$ & $(5.48,5.82)$ & $(2.67,2.93)$ & 3.47 & 3.22 & $(6.39,10.20)$ \\
\hline Percentages $(\%)$ & 28.46 & 17.25 & 8.55 & 10.58 & 9.84 & 25.32 \\
\hline Economic benefits $\left(10^{9}\right.$ USD) & $(5.53,6.31)$ & $(8.64,9.01)$ & $(4.39,5.01)$ & $(3.02,3.88)$ & $(2.02,2.20)$ & $(1.61,2.19)$ \\
\hline Percentages $(\%)$ & 22.00 & 32.82 & 17.46 & 12.82 & 7.83 & 7.07 \\
\hline
\end{tabular}




\subsection{Optimized Water Allocation for Ecology}

Overall, the ecological sector can receive a guaranteed water allocation of $8.237-12.354 \mathrm{~km}^{3}$, with an average of $10.295 \mathrm{~km}^{3}$, accounting for a $31.11 \%$ share of the total water supply. As the incoming flow level goes from high to low, the sector of ecology receives water allocation in order of 16.429-18.304, 12.943-16.590, 8.955-12.850, 1.553-8.862, and 1.057-1.460 $\mathrm{km}^{3}$. Provinces of A, B, C, D, E, and F, respectively receive an average ecological water allocation of $1.068,0.171,0.656,0.882,0.174$, and $7.343 \mathrm{~km}^{3}$. In F province (Karakalpakstan), in which the Aral Sea is located, allocated water in ecology amounts to $5.958-8.727 \mathrm{~km}^{3}$, meanwhile, total water demand is within the range of $10.165-10.575 \mathrm{~km}^{3}$, of which water demand for forestland, grassland, and waterbodies accounts for $6.90 \%$, $48.57 \%$, and $44.53 \%$ on average. Considering the optimal water allocation target value for ecology in F province as $10.575 \mathrm{~km}^{3}$, the corresponding total water shortage reaches $1.848-4.617 \mathrm{~km}^{3}$. According to the above, a rough estimate of $2.653-3.886 \mathrm{~km}^{3}$ guaranteed water is available for the Aral Sea.

\section{Conclusions}

As flows from the Amudarya River into the Aral Sea continue to decrease and human water withdrawal continues to increase, the water use competition between humans and ecology in the study area is becoming increasingly prominent. Thus, there is an obvious need to explore the optimization of the portion of water resources from the Amudarya River distributed to Uzbekistan. During the construction of the water system, the practical water policy was considered, which is that Uzbekistan and Turkmenistan share the flow of Amudarya River at Kerki gauging station, which strictly limits the water availability in the study area. Meanwhile, this study clarifies the actual influence range of the Amudarya River in Uzbekistan at the provincial level, with the result of six provinces (Kashkadarya, Samarkand, Navoiy, Bukhara, Khorezm, and Karakalpakstan) that are involved. Supply-demand balance analysis of the whole water system has been done, based on the calculations of water supply and water demand. The total sum of the water demand amounts to $40.173-45.704 \mathrm{~km}^{3}$, which exceeds the water supply under all incoming flow levels and under most guaranteed rates, and thus, water shortage exists and the optimal allocation work is necessary. This study aims at tackling the competition for water among different water use sectors in the study area at the provincial level under uncertainty. In the optimal allocation of available water, the optimization model of the ITSP method was used, which has proven to be effective in dealing with uncertainties in water resource allocation work and achieving the goal of maximization of economic benefits. The uncertainties are expressed as probability distributions or as interval values. In the model, unit economic benefits in all water users were calculated, including the ecological sector, which allows for an even-handed comparison among them and makes the optimization model more effective.

Through the above work, we have reached the following conclusions. (1) The corresponding water allocation schemes under uncertainty are given under different incoming water flow levels at the provincial level, and each scheme enables the entire study area to maximize the economic benefits with the least water use. (2) When compared with the actual water distribution, under high incoming flow level, the total allocated water of four sectors (except for ecology) is reduced by $3.706 \mathrm{~km}^{3}$ and total economic benefits are increased by USD 3.885B, which means that the optimization work plays a positive role in the allocation of water resources in the study area. (3) Water allocation among different sectors and different provinces has been optimally redistributed. Livestock, industrial, and municipality have the highest water allocation priority, and water competition mainly exists in the other two sectors of irrigation and ecology. From the provincial dimension, allocated water only in Bukhara and Khorezm can satisfy the upper bound of water demand. (4) At the same time, the ecological sector can receive a guaranteed water allocation of $8.237-12.354 \mathrm{~km}^{3}$, and there is a rough estimate of $2.653-3.886 \mathrm{~km}^{3}$ guaranteed water available for the Aral Sea. (5) In future research, more improvements will be planned. More 
emphasis will be placed on water competition between ecology and irrigation. Moreover, more details, such as the internal relationship among different water users and the limitations of actual engineering on the water supply capacity, will be considered to make the optimization model more accurate.

Author Contributions: Conceptualization, M.W., X.C. and P.D.; methodology, M.W.; formal analysis, M.W., L.C. and X.C.; data curation, A.S.; writing-original draft preparation, M.W.; writing-review and editing, X.C. and P.D.; supervision, X.C. and P.D.; project administration, X.C. and A.K. All authors have read and agreed to the published version of the manuscript.

Funding: This research was funded by the Strategic Priority Research Program of the Chinese Academy of Sciences, Pan-Third Pole Environment Study for a Green Silk Road (Grant No. XDA20060303), and the International Cooperation Project of the National Natural Science Foundation of China (Grant No. 41761144079).

Institutional Review Board Statement: Not applicable.

Informed Consent Statement: Not applicable.

Data Availability Statement: Data sharing is not applicable to this article.

Conflicts of Interest: The authors declare no conflict of interest.

\section{References}

1. Porkka, M.; Kummu, M.; Siebert, S.; Flörke, M. The Role of Virtual Water Flows in Physical Water Scarcity: The Case of Central Asia. Int. J. Water Resour. Dev. 2012, 28, 453-474. [CrossRef]

2. Mitchell, N.; Williams, R.B.; Hudson, D.; Johnson, P. A Monte Carlo analysis on the impact of climate change on future crop choice and water use in Uzbekistan. Food Secur. 2017, 9, 697-709. [CrossRef]

3. FAO. AQUASTAT Transboundary River Basin Overview-Aral Sea; Food and Agriculture Organization of the United Nations (FAO): Rome, Italy, 2012.

4. Ososkova, T.; Gorelkin, N.; Chub, V. Water Resources of Central Asia and Adaptation Measures for Climate Change. Environ. Monit. Assess. 2000, 61, 161-166. [CrossRef]

5. Der Beek, T.A.; Voß, F.; Flörke, M. Modelling the impact of Global Change on the hydrological system of the Aral Sea basin. Phys. Chem. Earth Parts A/B/C 2011, 36, 684-695. [CrossRef]

6. Djanibekov, N.; Frohberg, K.; Djanibekov, U. Income-based projections of water footprint of food consumption in Uzbeki-stan. Glob. Planet. Chang. 2013, 110, 130-142. [CrossRef]

7. Karthe, D.; Chalov, S.; Borchardt, D. Water resources and their management in central Asia in the early twenty first century: Status, challenges and future prospects. Environ. Earth Sci. 2015, 73, 487-499. [CrossRef]

8. Djumaboev, K.; Yuldashev, T.; Holmatov, B.; Gafurov, Z. Assessing Water Use, Energy Use and Carbon Emissions in Lift- Irrigated Areas: A Case Study From Karshi Steppe In Uzbekistan. Irrig. Drain. 2019, 68, 409-419. [CrossRef]

9. Yang, X.; Wang, N.; He, J.; Hua, T.; Qie, Y. Changes in area and water volume of the Aral Sea in the arid Central Asia over the pe-riod of 1960-2018 and their causes. Catena 2020, 191, 104566. [CrossRef]

10. Micklin, P.; Aladin, N.V. The Aral Sea: The Devastation and Partial Rehabilitation of a Great Lake; Springer: Berlin, Germany, 2014.

11. Kostianoy, A.G.; Kosarev, A.N. The Handbook of Environmental Chemistry: The Aral Sea Environment; Springer: Berlin, Germany, 2010.

12. Normatov, I.S. The water balance and the solution of water problems in the Central Asian region. IAHS Publ. 2004, 286, 300-314.

13. Rakhmatullaev, S.; Huneau, F.; Bakiev, M. Water reservoirs, irrigation and sedimentation in Central Asia: A first-cut assessment for Uzbekistan. Environ. Earth Sci. 2013, 68, 985-998. [CrossRef]

14. Muller, M. A General Equilibrium Approach to Modeling Water and Land Use Reforms in Uzbekistan. Ph.D. Thesis, University of Bonn, Bonn, Germany, 2006.

15. Schlüter, M.; Savitsky, A.G.; McKinney, D.C.; Lieth, H. Optimizing long-term water allocation in the Amudarya River delta: A water management model for ecological impact assessment. Environ. Model. Softw. 2005, 20, 529-545. [CrossRef]

16. Schlüter, M.; Rüger, N.; Savitsky, A.G.; Novikova, N.M.; Matthies, M.; Lieth, H. TUGAI: An Integrated Simulation Tool for Ecological Assessment of Alternative Water Management Strategies in a Degraded River Delta. Environ. Manag. 2006, 38, 638-653. [CrossRef] [PubMed]

17. Schlüter, M.; Leslie, H.; Levin, S. Managing water-use trade-offs in a semi-arid river delta to sustain multiple ecosystem services: A modeling approach. Ecol. Res. 2009, 24, 491-503. [CrossRef]

18. Schlüter, M.; Herrfahrdt-Pähle, E. Exploring Resilience and Transformability of a River Basin in the Face of Socioeconomic and Ecological Crisis: An Example from the Amudarya River Basin, Central Asia. Ecol. Soc. 2011, 16, 209-225. [CrossRef]

19. Schlüter, M.; Khasankhanova, G.; Talskikh, V.; Taryannikova, R.; Agaltseva, N.; Joldasova, I.; Ibragimov, R.; Abdullaev, U. Enhancing resilience to water flow uncertainty by integrating envi-ronmental flows into water management in the Amudarya River, Central Asia. Glob. Planet. Chang. 2013, 110, 114-129. [CrossRef] 
20. Lutz, A.F.; Droogers, P.; Immerzeel, W.W. Climate change impact and adaptation on the water resources in the Amu Darya and Syr Darya River basins. Rep. Future Water 2012, 2012, 110.

21. Jalilov, S.M.; Keskinen, M.; Varis, O. Managing the water-energy-food nexus: Gains and losses from new water development in Amu Darya River Basin. J. Hydrol. 2016, 539, 648-661. [CrossRef]

22. Jalilov, S.M.; Desutter, T.M.; Leitch, J.A. Impact of Rogun Dam on downstream Uzbekistan agriculture. Int. J. Water Resour. Environ. Eng. 2011, 3, 161-166.

23. Ruan, H.W.; Yu, J.J. Changes in land cover and evapotranspiration in the five Central Asian countries from 1992 to 2015. Acta Geogr. Sin. 2019, 74, 1292-1304.

24. Li, J.; Chen, H.; Zhang, C.; Pan, T. Variations in ecosystem service value in response to land use/land cover changes in Central Asia from 1995-2035. PeerJ 2019, 7, e7665. [CrossRef] [PubMed]

25. Huang, G.; Loucks, D.P. An inexact two-stage stochastic programming model for water resources management under uncertainty. Civ. Eng. Environ. Syst. 2000, 17, 95-118. [CrossRef]

26. Li, Y.; Huang, G. Inexact Multistage Stochastic Quadratic Programming Method for Planning Water Resources Systems under Uncertainty. Environ. Eng. Sci. 2007, 24, 1361-1378. [CrossRef]

27. Li, Y.P.; Huang, G.H.; Chen, X. Multistage scenario-based interval-stochastic programming for planning water resources allocation. Stoch. Environ. Res. Risk Assess. 2008, 23, 781-792. [CrossRef]

28. Dai, D.Y.; Li, Y.P.; Huang, G.H. A multistage irrigation water allocation model for agricultural land-use planning under uncertainty. Agric. Water Manag. 2013, 129, 69-79. [CrossRef]

29. Huang, Y.; Li, Y.; Chen, X.; Ma, Y. Optimization of the irrigation water resources for agricultural sustainability in Tarim River Basin, China. Agric. Water Manag. 2012, 107, 74-85. [CrossRef]

30. Ren, C.F.; Guo, P.; Tan, Q. A multi-objective fuzzy programming model for optimal use of irrigation water and land re-sources under uncertainty in Gansu Province, China. J. Clean. Prod. 2017, 164, 85-94. [CrossRef]

31. Suo, M.; Wu, P.; Zhou, B. An Integrated Method for Interval Multi-Objective Planning of a Water Resource System in the Eastern Part of Handan. Water 2017, 9, 528. [CrossRef]

32. Niu, G.; Li, Y.; Huang, G.; Liu, J.; Fan, Y. Crop planning and water resource allocation for sustainable development of an irrigation region in China under multiple uncertainties. Agric. Water Manag. 2016, 166, 53-69. [CrossRef]

33. Pienaar, G.W.; Hughes, D.A. Linking Hydrological Uncertainty with Equitable Allocation for Water Resources Decision Making. Water Resour. Manag. 2017, 31, 269-282. [CrossRef]

34. Li, M.; Sun, H.; Liu, D.; Singh, V.P.; Fu, Q. Multiscale modeling for irrigation water and cropland resources allocation con-sidering uncertainties in water supply and demand. Agric. Water Manag. 2021, 246, 106687. [CrossRef]

35. Bakker, H.; Dunke, F.; Nickel, S. A structuring review on multi-stage optimization under uncertainty: Aligning concepts from theory and practice. Omega 2020, 96, 102080. [CrossRef]

36. Sherafatpour, Z.; Roozbahani, A.; Hasani, Y. Agricultural Water Allocation by Integration of Hydro-Economic Modeling with Bayesian Networks and Random Forest Approaches. Water Resour. Manag. 2019, 33, 2277-2299. [CrossRef]

37. Tan, Q.; Liu, Y.; Zhang, X. Stochastic optimization framework of the energy-water-emissions nexus for regional power sys-tem planning considering multiple uncertainty. J. Clean. Prod. 2021, 281, 124470. [CrossRef] 